\title{
HEALTH RISKS RELATED TO TATTOO PROCEDURE
}

\author{
Aleksandra Tuchowska, , A, B, C, D Joanna Kruk, ,, D Paulina Sagan,, B, D Ewa Duchnik, 3, B \\ Mariola Marchlewicz ${ }^{1, A, D}$
}

\author{
${ }_{1}$ Pomeranian Medical University, Department of Aesthetic Dermatology, Poland \\ ${ }^{2}$ University of Szczecin, Faculty of Physical Culture and Health Promotion, Poland \\ ${ }^{3}$ Pomeranian Medical University, Department of Dermatology and Venereology, Poland \\ A Study Design; ${ }^{\text {B }}$ Data Collection; ${ }^{\text {C }}$ Statistical Analysis; ${ }^{\text {D Manuscript Preparation }}$ \\ Address for correspondence: \\ Mariola Marchlewicz \\ Department of Aesthetic Dermatology Pomeranian Medical University \\ Al. Powstańców Wielkopolskich 72, 70-111 Szczecin, Poland \\ E-mail: mariola.marchlewicz@pum.edu.pl
}

\begin{abstract}
Ahstract Nowadays, tattoos have become a very common form of body decoration. However, they carry a risk of numerous complications - ranging from allergies to cancer.

The study was divided into two parts. Adult persons, 156 men and 149 women, with one or more tattoos, participated in the first part of study. Anonymous respondents filled in the authorial questionnaire consisting of 14 questions and posted on the Internet. The second part of the study concerned of tattoo salons $(n=38)$ employees.

The aim of the study was to examine the awareness of people who are tattooing the body about the possible risks associated with such intervention, as well as the ability to obtain information from tattoo artists and analyze client cards in terms of the most important information about tattooing. The second part of the study was devoted to the analysis of the tattoo consent forms.

Most tattoo salons clients claimed that they signed a tattoo consent and were informed about contraindications and possible complications. However, only in very rare cases allergic tests were reported. There were few cases of complications among the respondents. There is a need to educate both the clients of tattoo salons and tattooists themselves. Attention should be paid to the necessity of filling in the informed consent.
\end{abstract}

Key Worlds tattoo, allergic reactions, infection, health risk, patient awareness

\section{Introduction}

Body tattooing has a very long history. The oldest tattoos are considered to be marks found on the skin of the ice man called Ötzi. The man who died more than 5,000 years ago in South Tyrol had more than fifty tattoos in the form of dashes and crosses created in the process of cutting the skin and rubbing charcoal in the wounds (Laux et al., 2016).

Over the centuries, skin marking has had a variety of functions on the social, individual and aesthetic background. Until recently, tattoos were the domain of criminals and seamen. Today, only in Europe, over 100 million 
people have one or more tattoos, which play different roles. There are medical tattoos, cosmetic tattoos, as well as those playing the role of decorations performed by professionals and amateurs (Laux et al., 2016; Nowak, 2012).

Today's tattoo inks contain a much richer composition, which mainly consists of dispersed pigments with solvents, and often also with impurities. Each of them must meet modern quality standards, which are updated each year (Ho, Goh, 2015).

\section{Tattoo inks ingredients}

The average tattoo ink contains about three preservatives approved for use in cosmetics, one astringent, three viscosity control components, at least three solvents, water and six or more pigments. The soluble and insoluble ingredients are micro- and nanoparticles with very different properties of absorption, distribution, metabolism and

excretion. Pigments as insoluble constituents are extremely slowly removed, while soluble components are usually eliminated quite quickly (Serup, Kluger, Bäumler 2015; Pajor, Broniarczyk-Dyła, Świtalska, 2015; Blume et al., 2017; Serup, Bäumler, 2017; Yongbum, Lee 2018).

Although modern tattoo inks contain mainly organic pigments, heavy metals such as nickel, antimony, arsenic, cadmium, chromium, cobalt and lead are clearly visible in the form of chromophores, shading additives or as impurities. Metal oxides, e.g. aluminum oxide or titanium oxide can be also detected. Their effects on the human body are still being studied (Kaur, Kirby, Maibach, 2009; Lehner et al., 2011; Kluger, Koljonen, 2012; Blume et al., 2017; Rogowska et al., 2018).

Black pigments used for most tattoos are a mixture of carbon black and polycyclic aromatic hydrocarbons. However, colored pigments have a much richer composition. They usually contain heavy metal compounds. Regardless of the color, the most common elements detected in the inks are nickel, oxygen, carbon and titanium. Moreover, red-colored inks used by tattoo-learning amateurs often contain toxic mercury (Bonadonna, 2015; Khunger, Molpariya, Khunger, 2015; Schreiver et al., 2016; Serup, Bäumler, 2017; Wilson, O’Boyle, Leach, 2018).

\section{Dangerous ingredients of tattoo inks}

Complications that may occur after tattooing can be divided into three groups: infections, allergic reactions and cancerous lesions. The most common changes associated with tattooing of the skin include acute inflammatory reaction, because of local and deep infection, systemic infection, allergic reactions, photodermatoses, granulomas. There are also skin diseases provoked by tattoos and located on tattooed areas, such as eczema, lichen planus, psoriasis and scleroderma (Kaur et al., 2009; Lehner et al. 2011; Serup et al., 2015; Rogowska et al., 2018; Yongbum, Lee, 2018).

One of the most common complications after the tattoo is the occurrence of hypersensitivity reactions. In the study of the toxicity of the inks used for performing tattoos, pyrolysis and chromatography was used to detect the parent compounds, it has been shown that among others, acrylates, including methyl methacrylate, ethyl methacrylate, dodecyl methacrylate are responsible for allergic reactions, 1-methyl-2-pyrrolidinone or styrene are responsible for other skin irritations. The presence of carcinogenic components (naphthalene, benzene, $\mathrm{N}$-vinylpyrrolidone) and toxic substances (styrene, toluene and ethylene glycol) was also shown. Other studies have also shown a significant exceeding the standards for ingredients that can cause allergies such as chromium, nickel or cobalt (Lehner et al., 2011; Schreiver et al., 2016; Blume et al., 2017). 
Due to the lack of standard methods to identify pigments in tattoo inks, it is possible to bypass legal regulations and hide some of the components due to the quantity of given substance being too small to detect (Blume et al., 2017).

Research on black tattooing inks have shown the content of at least some substances dangerous for the body. This is, inter alia, dibutyl phthalate, which acts directly on keratinocytes and may elicit Th2 lymphocytes reaction after exposure to the skin. Another component threatening human health is hexachlor-1,3-butadiene exhibiting genotoxic activity in vitro. The presence of 9 -fluorenone, which is characterized by cytotoxicity producing reactive oxygen species in conditions of exposure to light, was also found in inks (Serup, Bäumler, 2017).

\section{Complications after tattoo procedures}

Breaking of skin barrier to inject a dye into the dermis while making a tattoo increases the risk of infection. Even every twentieth person suffers from a bacterial infection after making a tattoo (Lehner et al., 2011; Pajor et al., 2015, Serup et al., 2015). Colored tattoos are particularly dangerous. The most frequent allergic reactions were noted in the case when red, less often blue and green dyes had been used. Symptoms of hyperkeratosis and keloids are also observed. In the case of black inks, papulo-tuberous and non-allergic reactions were observed as a result of the agglomeration of nanoparticle of the pigments (Ho, Goh, 2015; Serup, Bäumler, 2017; Yongbum, Lee, 2018).

Additionally, tattoo inks may be contaminated with microorganisms. This constitutes a great risk of hepatitis $B$ and hepatitis $C$, and HIV viruses infection. In addition, carcinogenic inks ingredients have also been researched in recent years. Currently, the International Agency for Research on Cancer classifies only several components of tattooing inks as potentially carcinogenic to humans, such as mercury, cobalt sulphate, other soluble salts of cobalt and carbon black (Ho, Goh, 2015; Schreiver et al., 2016).

As part of ensuring microbiological safety, preservatives and sterilization with beta or gamma radiation are used (Serup et al., 2015).

The aim of the study was to examine the awareness of people undergoing tattooing the body about the possible risks associated with such procedure, as well as the possibility of obtaining information on the subject from tattoo artist and analyzing the customer cards of tattoo salon's clients in terms of the most important information concerning tattooing.

\section{Material and methods}

The study was carried out in two parts. The first part of the study was addressed to clients of tattoo salons, while the second part of the study concerned of tattoo salons employees.

Adults, 156 men and 149 women, over 18 years old, that had one or more tattoos participated in the first part of the study. Respondents completed the original questionnaire consisting of 14 questions (closed and semi-open) that was posted on the Internet. People who took part in study were anonymous and came from all over Poland.

The second part of the study was devoted to the analysis of consent cards for tattooing. The forms of documents were acquired out electronically. In order to get access to the tattoo consent card, requests were sent to 62 random tattoo salons from all over Poland. Answers were received from 38 studies that expressed a desire to cooperate.

The limiting factor in the research was the inability to determine whether the consent card to the tattoo is actually supplemented with, among others, an oral interview or assessment of skin condition. Only the content of the submitted documents has been subject to analysis. 


\section{Results of first part of the study}

More than half of the respondents from the first part of the study, both female and male came mainly from the cities with more than 100,000 inhabitants. Up to 111 women and 104 men declared having higher education among. There was no respondent with lower than secondary education.

The most numerous group of respondents ( $70 \%$ women and $62 \%$ men) performed the first tattoo between 19 and 30 years of age. The least numerous group were the respondents who decided to tattoo the body after 40 years of age. In case of 6 women and 15 men a tattoo was made on underage people. Respondents most often declared their desire to embellish the body and stand out from the crowd as the reason for performing the tattoo. To a lesser extent, people wanted to commemorate the important moment with the tattoo. However, the smallest percentage of men and women made the tattoo at the instigation of friends and because of the prevailing fashion. The people who took part in the research most often had their tattoos made by professional tattooists. Every tenth man declared that the tattoo was done by a person learning the profession. Only one woman and 4 men admitted that they made their tattoos themselves.

Before the tattoo was made, in most cases the consent for the procedure was signed. Among respondents, $13 \%$ of men and $10 \%$ of women with more than one tattoo declared that the consents were not signed each time; and $3 \%$ of women and $14 \%$ of men admitted that they did not sign any documents related to consenting to the procedure. There were extremely rare cases of carrying allergic tests before tattooing among the respondents. This applied only to 4 people ( 3 women and $1 \mathrm{man}$ ) in the group of 305 respondents. In the case of making clients aware of the existence of contraindications and the possibility of complications, the results were more satisfactory because $82 \%$ of women and $74 \%$ of men declared that they were informed of possible complications each time before the tattoo was made. However, 7 women and 13 men admitted that they were not given such information at all. The other respondents replied that the necessary information had been provided to them, but not before each tattoo.

Among respondents, almost half of men and $60 \%$ of women declared that they were witnesses of unpacking sterile tools before making a tattoo. Every third person admitted that they were not present during this activity at every visit to the tattoo salon. However, every fifth man and $13 \%$ of women were unsure whether the tools used were sterile.

Complications after tattooing occurred in 6 women and 12 men. The most common complication in both groups was the occurrence of a severe redness. The frequency of other complications is shown in the tables (Table 1 and Table 2).

Table 1. Complications after tattooing in women

\begin{tabular}{lcc}
\hline \multicolumn{1}{c}{ A type of complication occurring in women } & Occured & Did not occur \\
\hline Severe redness & 10 & 139 \\
Allergic reaction & 3 & 146 \\
Bacterial or fungal infection & 1 & 148 \\
Scars or keloids & 2 & 147 \\
Granulomas & 1 & 148 \\
Muscle atrophy & 0 & 149 \\
Other & 0 & 0 \\
\hline
\end{tabular}


Table 2. Complications after tattooing in men

\begin{tabular}{|c|c|c|}
\hline $\begin{array}{l}\text { A type of complication occurring among men } \\
\qquad n=156\end{array}$ & Occured & Did not occur \\
\hline Severe redness & 14 & 142 \\
\hline Allergic reaction & 3 & 153 \\
\hline Bacterial or fungal infection & 1 & 155 \\
\hline Scars or keloids & 1 & 155 \\
\hline Granulomas & 0 & 156 \\
\hline Muscle atrophy & 0 & 156 \\
\hline Other & 0 & 0 \\
\hline
\end{tabular}

\section{Results of the second part of the study}

All the consents for the procedure were characterized by a similar structure. Each document includes the name of the salon, the type of procedure to be performed, a place to enter the data of the person undergoing the procedure and to sign it with the date and place. In terms of other aspects, the cards differed from each other. It was noticed that in the case of 14 of 38 tattoo salons, there is no room for entering the tattoo artist's details. In addition, only every 5 studios have information about the course of tattooing and the possibility of complications in the card. Confirmation of the possibility of asking questions and withdrawing consent was on 8 pages. Half of the salons did not inform clients in writing about possible contraindications. In more than $50 \%$ of approvals, no confirmation from the client about the understanding of the information provided was found. However, it was noticed that most salons (87\%) expand their consent cards for information about home care recommended after the tattoo. Additional information that was included in $60 \%$ of the consent cards included the customer's confirmation that the tools used to make the tattoo were sterile and unpacked in their presence. Nearly half of the submitted documents also included annotations that the client would not claim a person performing the procedure because they were familiar with the risks that the procedure carries.

\section{Discussion}

According to the current legal status in Poland, the patient should agree to the procedure before it is performed. Due to the fact that the tattoo appears in the International Classification of Medical Procedures as a form of surgery performed by the aesthetic medicine doctor, the consent for the procedure should also be obtained from clients of tattoo salons. There are various forms of patient authorization. Usually, simple consent is given, expressed orally or through gestures and written consent. In tattoo salons, written consent is usually applied.

The performed study shows, that consents for tatoo procedures are not as expanded as those for medical procedures and do not contain all the necessary elements. We can assume that some of them have been completed with client history and trough necessary oral information, which is also allowed according to the Polish law. On the other hand, analyzing the respondents' answers it can be assumed that the obligation to provide information was often unfulfilled (Baron, 2010; Kubiak, 2018; Lis, 2018; Międzynarodowa Klasyfikacja Procedur Medycznych, 2019). 


\section{Conclusions}

Body tattooing is a procedure of great interference and the clients of tattoo salons should be aware of it. Information on all aspects of the tattoo should be mandatorily provided by the person performing the procedure. At this point, it is important to educate the tattooists themselves, who when taking up their profession, also accept the risks they may incur in the event of post-tattoo complications. It seems important to collect informed consents from each client, which will be developed based on medical documents. This will help in raising the awareness of customers and tattooists, as well as in reducing the occurrence of complications. Attention should also be paid to allergic tests, which as the study has proven, are very rarely made.

\section{References}

Baron, K. (2010). Zgoda pacjenta. Prokuratura i Prawo, 9, 42-57.

Blume, A., Janssen, P.J.M.C., Krätke, R., Serup, J.V., Andersen, I.S., Talberg, H.J., Verdier, C. (2017). Safer tattooing: overview of current knowledge and challenges of toxicological assessment. Strasbourg. Council of Europe.

Bonadonna, L. (2015). Survey of studies on microbial contamination of marketed tattoo inks. Tattooed Skin and Health, 48, $190-195$.

Ho, S.G., Goh, C.L. (2015). Laser tattoo removal: a clinical update. Journal of cutaneous and aesthetic surgery, 8 (1), 1-9.

Kaur, R.R., Kirby, W., Maibach, H. (2009). Cutaneous allergic reactions to tattoo ink. Journal of cosmetic dermatology, 8 (4), 295-300.

Khunger, N., Molpariya, A., Khunger, A. (2015). Complications of tattoos and tattoo removal: stop and think before you ink. Journal of cutaneous and aesthetic surgery, 8 (1), 30-36.

Kluger, N., Koljonen, V. (2012). Tattoos, inks, and cancer. The lancet oncology, 13 (4), 161-168.

Kubiak, R. (2018). Sposób udzielania informacji medycznej. Palliative Medicine/Medycyna Paliatywna, 10 (2), 56-64.

Laux, P., Tralau, T., Tentschert, J., Blume, A., Dahouk, S.A., Bäumler, W., Bernstein, E., Bocca, B., Alimonti, A., Colebrook, H., de Cuyper, C., Dähne, L., Hauri, U., Howard, P.C., Janssen, P., Katz, L., Klitzman, B., Kluger, N., Krutak, L., Platzek, T., Scott-Lang, V., Serup, J., Teubner, W., Schreiver, I., Wilkniß, E., Luch, A. et al. (2016). A medical-toxicological view of tattooing. The Lancet, 387 (10016), 395-402.

Lehner, K., Santarelli, F., Vasold, R., König, B., Landthaler, M., Bäumler, W. (2011). Black tattoo inks are a source of problematic substances such as dibutyl phthalate. Contact Dermatitis, 65 (4), 231-238.

Lis, W. (2018). Zgoda pacjenta na czynność medyczną w polskim porządku prawnym. Zeszyty Naukowe KUL, 61 (3), 39-58.

Międzynarodowa Klasyfikacja Procedur Medycznych. Retrieved from: http://www.icd9.pl (14.01.2019).

Nowak, R. (2012). Psychologiczne aspekty tatuowania się. Roczniki Psychologiczne, 2 (15), 87-104.

Pajor, A.J., Broniarczyk-Dyła, G., Świtalska, J. (2015). Satysfakcja z życia, poczucie własnej wartości oraz ocena zdrowia psychicznego u osób z tatuażem lub piercingiem. Psychiatria Polska, 49 (3), 559-573.

Rogowska, P., Szczerkowska-Dobosz, A., Kaczorowska, R., Słomka, J., Nowicki, R. (2018). Tattoos: Evaluation of knowledge about health complications and their prevention among students of Tricity universities. Journal of cosmetic dermatology, 17 (1), $27-32$.

Schreiver, I., Hutzler, C., Andree, S., Laux, P., Luch, A. (2016). Identification and hazard prediction of tattoo pigments by means of pyrolysis - gas chromatography/mass spectrometry. Archives of toxicology, 90 (7), 1639-1650.

Serup, J., Bäumler, W. (2017). Diagnosis and therapy of tattoo complications: with atlas of illustrative cases. Basel: Karger Medical and Scientific Publishers.

Serup, J., Kluger, N., Bäumler, W. (2015). Tattooed skin and health. Basel: Karger Medical and Scientific Publishers.

Wilson, W.T., O'Boyle, M., Leach, W.J. (2018). Unusual complication of a tattoo in an immunosuppressed patient. Case Reports. BMJ. DOI: 10.1136/bcr-2018-224968.

Yongbum, K.W.O.N., Lee, D.G. (2018). Considering an Approach for Assessing the Relevance of Tattoo-associated Health Risk from an Overall Toxicological Perspective. Iranian Journal of Public Health, 47 (5), 755-756.

Cite this article aS: Tuchowska, A., Kruk, J., Sagan, P., Duchnik, E., Marchlewicz, M. (2019). Health Risks Related to Tattoo Procedure. Central European Journal of Sport Sciences and Medicine, 2 (26), 41-46. DOI: 10.18276/cej.2019.2-04. 